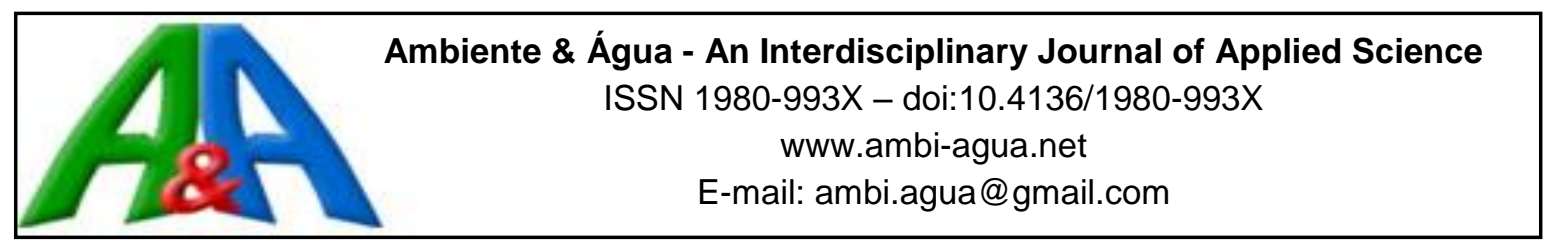

\title{
Comparison of the physical, chemical and biological parameter magnitudes and cyanobacterial bloom in the Alagados reservoir of Ponta Grossa - PR
}

\author{
ARTICLES doi:10.4136/ambi-agua.2016
}

Received: 27 Sep. 2016; Accepted: 07 Feb. 2018

\author{
Andressa Beló $^{1 *}$; Alvaro Luiz Mathias ${ }^{2}$; Carlos Alberto Ubirajara Gontarski² \\ ${ }^{1}$ Companhia de Saneamento do Paraná (SANEPAR), Ponta Grossa, PR, Brasil \\ E-mail: dressabelo@yahoo.com.br \\ ${ }^{2}$ Universidade Federal do Paraná (UFPR), Curitiba, PR, Brasil \\ Departamento de Engenharia Química (DEQ).E-mail: mathias@ufpr.br, gontarski@ufpr.br \\ *Corresponding author
}

\begin{abstract}
The cyanobacterial bloom is a consequence of eutrophication in a lentic environment. It is attributed to the contribution of nutrients related to anthropic action, as well as geographic and physico-chemical conditions. Water quality parameters of Alagados reservoir, which supplies Ponta Grossa, were determined between 08/2013 and 08/2014 to evaluate their effects on the occurrence of bloom. Some parameters, such as pH (9.1), DO (4.2 $\left.\mathrm{mg} \mathrm{L}^{-1}\right)$, BOD (39 $\left.\mathrm{mg} \mathrm{L}^{-1}\right)$, TP $\left(0.86 \mathrm{mg} \mathrm{L}^{-1}\right)$ and number of cyanobacterial cells $\left(372,536\right.$ cells $\left.\mathrm{mL}^{-1}\right)$, were outside the limits recommended by CONAMA 357/05 for Class II and Decree 2,914/11 of the Ministry of Health. The bloom was predominantly caused by the overdevelopment of Cylindrospermopsis sp. and required additional use of chemical products in the treatment of municipal water supplies, to include coagulant $(19.6 \%)$, polymer $(21.0 \%)$ and activated carbon $(1,889 \%)$, with a corresponding cost increase of 58\%. The Water Quality Index confirmed the worsening of reservoir water quality during bloom. The Principal Component Analysis of historical data $(01 / 2003$ to $08 / 2014)$ did not discriminate the cyanobacteria levels classes $(<2,000,2,000$ 20,000, 20,000-50,000 and > 50,000 cells $\mathrm{mL}^{-1}$ ) based on Brazilian standards, which was confirmed by the Hierarchical Cluster Analysis; although it confirmed a logical correlation between some parameters (climatic condition-reservoir rainfall-reservoir level and BODCOD). The unidentified correlations can be attributed to the adaptability of Cylindrospermopsis sp. and the ecological complexity that requires higher sampling frequency.
\end{abstract}

Keywords: conservation, eutrophication, reservoir impacts.

\section{Comparação de floração de cianobactérias e níveis de parâmetros físicos, químicos e biológicos na represa de Alagados, Ponta Grossa - PR}

\section{RESUMO}

A floração de cianobactérias é consequência da eutrofização em ambiente lêntico e é atribuída ao aporte de nutrientes relacionado à ação antrópica, além de condições geográficas e físico-químicas. Parâmetros de qualidade da água da bacia de Alagados, que abastece Ponta 
Grossa, foram determinados entre 08/2013 e 08/2014 para avaliar seus efeitos na ocorrência de floração. Alguns parâmetros foram encontrados fora dos limites, como pH $(9,1)$, OD (4,2 $\left.\mathrm{mg} \mathrm{L}^{-1}\right)$, DBO (39 $\left.\mathrm{mg} \mathrm{L}^{-1}\right)$, PT $\left(0,86 \mathrm{mg} \mathrm{L}^{-1}\right)$ e número de células de cianobactérias (372.536 céls $\mathrm{mL}^{-1}$ ); CONAMA 357/05 classe II e Portaria 2.914/11 do Ministério da Saúde. A piora da qualidade da água da represa durante a floração foi confirmada com uso do Índice de Qualidade de Água. A floração de Cylindrospermopsis sp. demandou uso suplementar de insumos químicos no tratamento de água, como coagulante $(19,6 \%)$, polímero $(21,0 \%)$ e carvão ativado (1.889\%), com correspondente aumento de custo em 58\%. A Análise de Componentes Principais de dados históricos (01/2003 a 08/2014) não discriminou as classes de níveis de cianobactérias $\left(<2.000,2.000-20.000,20.000-50.000\right.$ e $>50.000$ cél ml $\left.^{-1}\right)$ baseadas em normas brasileiras, o que foi confirmado pela Análise Hierárquica de Agrupamentos; embora tenha confirmado correlação lógica entre alguns parâmetros (condição climática, índice pluviométrico da bacia, nível da represa e DBO-DQO). As correlações não identificadas podem ser atribuídas à adaptabilidade da Cylindrospermopsis sp. e a complexidade ecológica que demanda maior frequência de amostragem.

Palavras-chave: conservação, eutrofização, impactos de reservatórios.

\section{INTRODUCTION}

The availability of drinking water is related to the economic development of a geographical area, which may require changes in the water system, such as the collection of water in artificial basins and the damming of rivers (Tucci and Mendes, 2006). These lentic systems limit the renewal of water segments and accelerate degradation processes (Nakamura and Rast, 2011). Another anthropogenic activity is the increase in the nutrient load of reservoirs, resulting in eutrophication. Excessive growth of cyanobacteria causes serious problems for the environment and public health. The Alagados Reservoir is an example of a water source that exhibits frequent and intense blooms of microalgae and cyanobacteria (Yunes et al., 2003), which have been monitored since 2003 (SANEPAR, 2014). The reservoir being studied is an ecosystem with vast biodiversity. It is located in the Campos Gerais region and bridges the Escarpa Devoniana range, belonging to the water reservoir of the Tibagi River, which is considered one of the largest and most important in Brazil, economically, physically, and hydrologically. Within the Alagados Reservoir, activities such as agriculture, livestock breeding, and reforestation using exotic plants such as Pinnus spp and Eucalyptus spp is carried out. In addition, the area is used for leisure activities with potential for being a site for tourism, as well as being a water source for electric power generation and public water supply (SANEPAR, 2010).

A water treatment plant should be able to supply water that is adequate for human consumption, with appropriate sanitary and toxicological characteristics. Therefore, blooming of cyanobacteria such as of the Microcystis, Cylindrospermopsis, Anabaena, and Oscillatoria species in water sources is a serious problem (Hitzfeld et al., 2000; SANEPAR, 2014). The blooming may alter the quality of the treated water and cause operational problems at various stages of treatment, such as a loss in efficiency during the decantation operation, reduction in operation (run) time during filtration, greater water consumption during the washing of the filters, and an overall reduction in the production of treated water (Di Bernardo e Dantas, 2005; De Julio et al., 2010). The water supply system of the municipality of Ponta Grossa (state of Paraná) captures surface water from the Alagados Reservoir (40\% of the total demand) and from the Pitangui River, downstream from the reservoir, in order to supply 350,000 inhabitants. There are two treatment stations, the Pitangui WTS (for conventional treatment) and the Actiflo WTS, designed to deliver a high-performance decantation process over a low area of coverage. 
The monitoring and study of water reservoirs are important tools for environmental management since they provide data that contribute to a diagnosis of the impacts and risks of degradation on water resources (Nakamura and Rast, 2011). The goal of this study was to use mathematical and statistical tools to evaluate factors that exhibit a potential correlation to the blooming of cyanobacteria in the Alagados Reservoir, as well as their effect on water treatment for urban consumption.

\section{MATERIALS AND METHODS}

\subsection{Study area, sampling, and methodology}

The Alagados Reservoir is part of the Tibagi River Reservoir, located in the southwest quadrant of the state of Paraná, delimited by the coordinates $24^{\circ} 52^{\prime}$ to $25^{\circ} 05^{\prime}$ ' S and $49^{\circ} 46^{\prime}$ to $50^{\circ} 06^{\prime} \mathrm{W}$, and encompassing the municipalities of Ponta Grossa, Castro, and Carambeí.

Monthly collections were carried out during the period from August 2013 to August 2014 at 10 locations along the course of the main tributaries, the Jotuba River (J2 and J4), the Pitangui River (P1, P2, P3 and P4) and at the reservoir (R1, R2, R3 and R4). In the month of December, the samples were taken only at the point near the (R4) location (due to lack of staff). The same is true for the months of February, April, and May (due to the impossibility of navigation as a result of low water levels in the reservoir during the dry season). The water samples were collected at the water surface in the Alagados Reservoir between the hours 09:30 a.m. and 3:00 p.m., simultaneously by boat and by automobile. Water temperature, air temperature, climate conditions, water transparency (using a Secchi disk), and rainfall were determined in situ. For statistical analysis of the water quality index at point R4, samples were collected at an average depth of 3 meters and from the bed of the reservoir (using a Van Dorn bottle), in addition to the surface samples.

The samples were conditioned and transported in thermal boxes for subsequent analysis of $\mathrm{pH}$, turbidity, ammoniacal nitrogen, nitrite, nitrate, conductivity, total phosphorus (TP), reactive phosphorus (RP), dissolved oxygen (DO), biochemical oxygen demand (BOD), chemical oxygen demand (COD), and Escherichia coli (E. coli). The sampling for cyanobacteria cell count was carried out at the reservoir collection point at 10:00 a.m. The methodologies used were those described in Standard Methods for the Examination of Water and Wastewater. The water level in the reservoir was evaluated by direct measurement. The rainfall data (ÁGUASPARANÁ - Water Institute of Paraná) and insolation data for the municipality of Castro-PR (INMET - National Institute of Meteorology) were obtained from the free access database. The water treatment stations (WTS) of the municipality of Ponta Grossa were monitored during this period in order to evaluate the impact on the process.

\subsection{Statistical analyzes}

The Water Quality Indices for the junction of the rivers (WQIri) and for the reservoir (WQIre) were used to discriminate among four classes, according to Conama Resolution 357/05 - excellent, good, normal, and poor. Each parameter was weighted according to its importance. The parameters considered for the WQIri, listed in descending order of importance, were as follows: DO, COD, E. coli, TP, pH, total nitrogen (TN), turbidity, and total dissolved solids (TDS). Parameters for WQIre were as follows: cyanobacteria, DO, COD, TP, transparency, time of residence, TN, and average depth. The reservoir index was based on the index used by the Environmental Institute of Paraná (IAP), which was adapted for conditions specific to SANEPAR (SANEPAR, 2014). The multivariate calibration was conducted using historical data from SANEPAR from January of 2003 to August of 2014. The Principal Component Analysis (PCA) was conducted using the technique involving auto-scalar preprocessing, without rotation, 10 factors (for optimization), with a 95\% interval of confidence, and 
Hierarchical Cluster Analysis (HCA) was conducted using an auto-scalar preprocessing technique, Euclidean distance, and an incremental linking method. Both used the Pirouette software, Version 4.5.

\section{RESULTS AND DISCUSSION}

\subsection{Analysis of water quality in the Alagados Reservoir and tributaries}

The blooming of cyanobacteria is a multifactorial phenomenon, and several physicalchemical and biological parameters have been described as having a positive correlation (Andreoli and Carneiro, 2005; Wu et al., 2012); therefore, the purpose of monitoring of the water quality in the Alagados Reservoir $(\mathrm{Ri}, \mathrm{i}=1-\mathrm{n})$ and its major tributaries $(\mathrm{Jj}$ and $\mathrm{Pj}, \mathrm{j}=1-\mathrm{m})$, was to verify the contribution of each location in the total input of nutrients, as well as other parameters that may influence the cyanobacteria blooming process in the reservoir. The results of the surface samples during periods in which occurred blooming (WB, between February and June of 2014) superior to 20,000 cell $\mathrm{mL}^{-1}$, and those without blooming (the remaining months), no clear correlation pattern emerges (Figures 1, 2, and 3).

The temperature of the water in the reservoir was higher than that of the rivers, possibly a result of the larger surface area, which absorbs more heat, as well as the inferior shade was compared to that of the rivers (especially the Pitangui), provided by riparian growth. Escherichia coli, which comprises $95 \%$ of fecal coliforms, has been used as a bioindicator of fecal contamination. Its levels vary between $<1$ and 2,420 NMP $100 \mathrm{~mL}^{-1}$ in the Jotuba and Pitangui, the lowest values were observed at the locations in the reservoir.
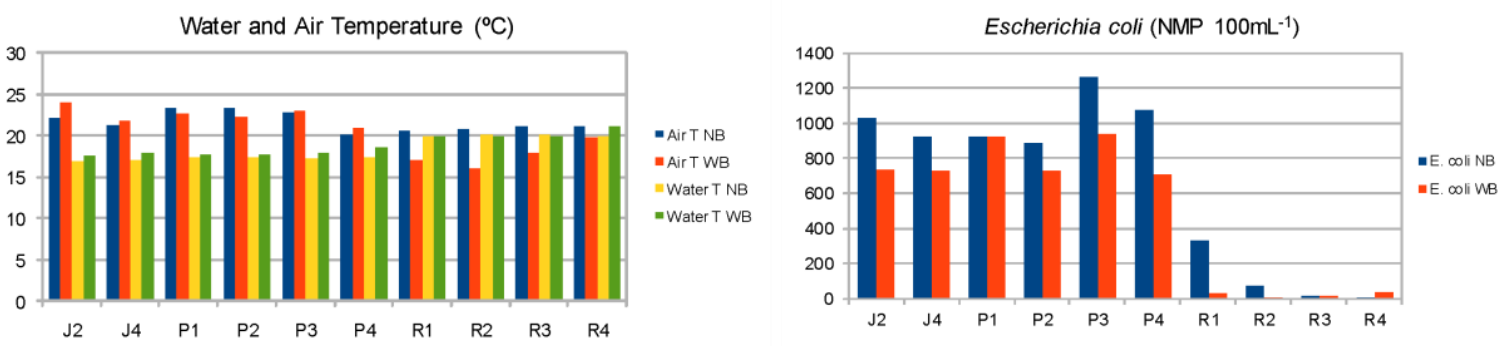

Figure 1. Monthly averages of the air and water temperatures, and microbiological averages during the periods exhibiting no blooming (NB) and those with blooming (WB) of cyanobacteria in the Alagados Reservoir from August 2013 to August 2014.
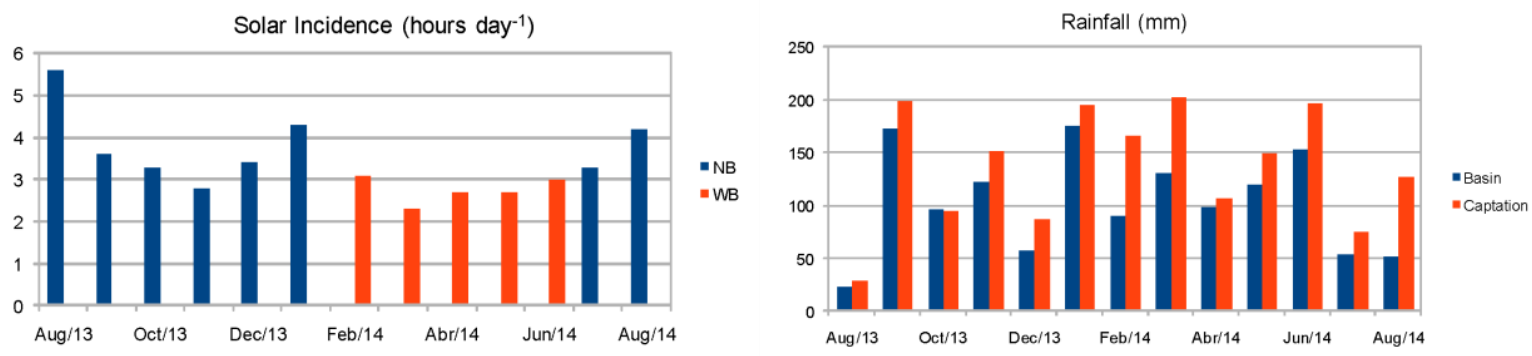

Figure 2. Monthly insolation and rainfall averages during the periods exhibiting no blooming (NB) and those with blooming (WB) of cyanobacteria in the Alagados Reservoir from August 2013 to August 2014. 

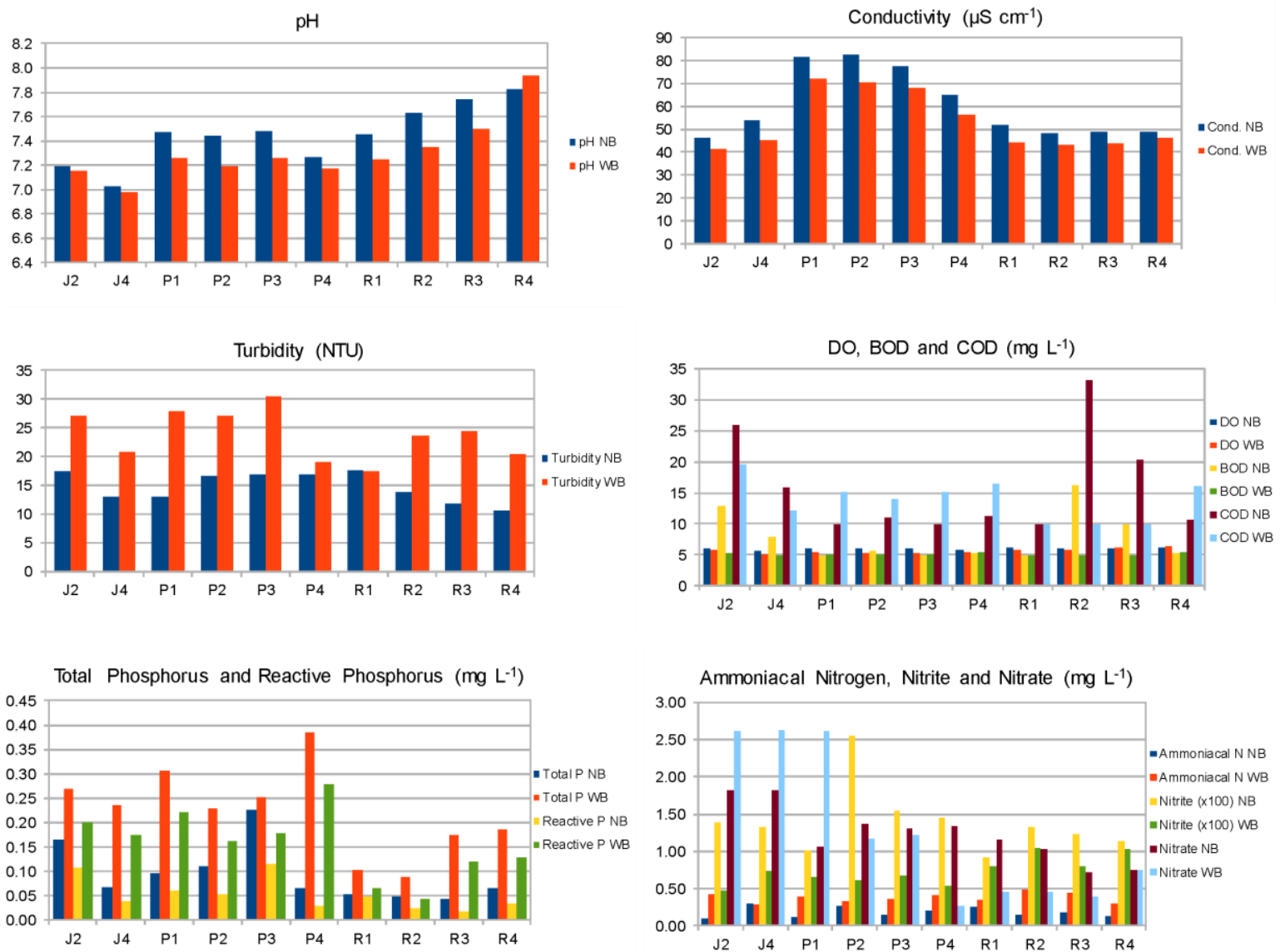

Figure 3. Monthly averages of the physical-chemical parameters during the periods exhibiting no blooming (NB) and those with blooming (WB) of cyanobacteria in the Alagados Reservoir from August 2013 to August 2014.

According to Conama 357/05, Class II framework, its MPV (maximum permissible value) in bodies of water should be lower than $1,000 \mathrm{NMP} 100 \mathrm{~mL}^{-1}$ for $80 \%$ or more of the analyzed samples; this occurred in $74 \%$ of the samples evaluated in the entire reservoir. The comparison of the monthly averages in the periods with and without blooming exhibited a substantial difference between the tributaries and the reservoir. The largest values were observed in the course of the Pitangui River, located near the junction of the river with the reservoir; this may possibly be attributed to pollution from domestic sewage, animal waste, or both. The lower levels observed in the reservoir may be a result of dilution due to the larger water volume.

Solar incidence was greater in August, the month in which the rainfall index is usually lower. Summer days are longer and warmer, and therefore insolation tends to be greater. The average insolation increased from November to January, the month preceding cyanobacteria blooming. This phenomenon generally occurs at a temperature of $20^{\circ} \mathrm{C}$, but it may be influenced more intensely by solar radiation, since a description exists of blooming in species that developed in cold periods that nevertheless had a high incidence of light (Yunes et al., 2003).

The rainfall regime may alter the water quality, as a result of alterations in the physicalchemical and biological characteristics, as well as eutrophication (Sosnovsky and Quirós, 2006). Precipitation in the reservoir varied from $23 \mathrm{~mm}$ (August of 2013) to $173 \mathrm{~mm}$ (January of 2014) (ÁGUASPARANÁ), and was similar to that of the water collection area, which varied from 29mm (August of 2013) to $202 \mathrm{~mm}$ (March of 2014) (SANEPAR, 2014). There was little rainfall in the month of August of 2013, a result that is compatible with the drier winters normally experienced in the region. The rainiest period, between December and February, exhibits average values of 500 to $600 \mathrm{~mm}$; however, the value actually observed was $325 \mathrm{~mm}$ 
(ÁGUASPARANÁ). Thus, the reservoir levels were lower than normal, a fact that may have influenced the study. Above $10.00 \mathrm{~m}$ of the water level, excess water is drained by the spillway, a fact that was observed only in September. Because of this fact, in the months of February, April, and May, it was only possible to carry out sample collection at Point R4 of the reservoir. The other points were not accessible because the trunks of dead trees and sandbars prevented navigation.

The $\mathrm{pH}$ values varied between 6.4 for the Jobuba River (J4) in May to 9.1 for the reservoir (R4) in February; the second of these cases occurred with blooming (WB). This result, which is above the limit stipulated by Conama 357 for Class II, is a characteristic of an environment in which eutrophication has taken place. The $\mathrm{pH}$ is directly related to the process of photosynthesis, and alkaline results are a result of a decrease in the concentration of carbon dioxide in the water (Wetzel, 2001). Conductivity varied from $31 \mu \mathrm{S} \mathrm{cm}^{-1}$ in the Jotuba River to $98 \mu \mathrm{S} \mathrm{cm}^{-1}$ in the Pitangui River, thus exhibiting saline content levels that are similar or below the $100 \mu \mathrm{S} \mathrm{cm}^{-1}$, considered aggressive toward the ecosystem. Turbidity varied between 5.1 and 94.6 NTU and therefore was lower than the maximum permitted value, MPV (100 NTU), according to Conama 357, for water in a Class II framework. The greater turbidity and conductivity values at the Pitangui River monitoring points may be due to erosion of the riverbanks during the rainy seasons due to the low levels of vegetation cover. For example, one section of the Pitangui River is particularly lacking in riparian vegetation, instead having intensely cultivated areas that may have contributed to the greater quantities of surface runoff of soil arriving at the river. The greater amplitude of turbidity observed is related to the periods with and without cyanobacteria blooming, according to which the averages during the WB period are significantly greater than those of the NB period. This may be attributed to the presence in the reservoir of algae, cyanobacteria, and plankton in general. The DO values varied from 4.2 in the Jotuba River (R4) in May (WB), to $8.5 \mathrm{mg} \mathrm{L}^{-1}$. The BOD varied from $39 \mathrm{mg} \mathrm{L}^{-1}$, the greatest value, to the detectable limit, DL $\left(<3 \mathrm{mg} \mathrm{L}^{-1}\right)$, and the greatest value was observed in the reservoir (R2) in October. The COD parameter varied from $<5$ to $78 \mathrm{mg} \mathrm{L}^{-1}$, the greatest result was found in the reservoir (R2), also in October (WB); these findings are compatible with those of the BOD. According to the Conama 357, Class II legislation, the DO result must not be inferior to $5 \mathrm{mg} \mathrm{L}^{-1}$ and the BOD must be inferior to $5.0 \mathrm{mg} \mathrm{L}^{-1}$, revealing that stress existed for aquatic animals, confirming an oxygen demand that was above what is recommended, compatible with a low availability of oxygen. Thus, it is up to a detailed study to identify a possible contamination by animal waste, debris, rubbish, or even the agricultural sprayers in the Alagados Reservoir. The BOD and COD values were similar, which is compatible with components that are easily biodegradable. The highest values were observed in the reservoir (Point R2), where there is agricultural and livestock activity, the BOD being higher in pasture areas than in forests (Castro et al., 2009).

The total phosphorus content varied from $0.86 \mathrm{mg} \mathrm{L}^{-1}$ in the Pitangui River (P4) in February (WB), to DL $\left(<0.02 \mathrm{mg} \mathrm{L}^{-1}\right)$, whereas reactive phosphorus, or bioavailable phosphorus, varied from $0.65 \mathrm{mg} \mathrm{L}^{-1}$ at the same location and time cited previously, to the DL $\left(<0.01 \mathrm{mg} \mathrm{L}^{-1}\right)$. Only $11 \%$ of the samples were found to be within the limits prescribed in the Conama 357/05, Class II legislation. The average concentration of these forms of available phosphorus was much higher in the months with cyanobacteria blooming as compared to those in which there was no blooming, a finding compatible with a positive correlation for phosphorus content, which is considered the main element responsible for anthropic eutrophication in continental waters. Thus, external sources must be monitored in order to limit the cyanobacteria population to the desired levels (Conley et al., 2009; Jacoby and Frazer, 2009). This reservoir was built in 1929, and has undergone natural aging, in addition to the availability of nutrients resulting from the reduction of riparian vegetation, cumulative agricultural and livestock 
activity, and the partial urbanization of its edges (Conley et al., 2009); agriculture and livestock activities use feedstocks that contain P and N in their composition (Sosnovsky e Quirós, 2006).

Nitrogen is generally not considered a limiting nutrient in the eutrophication of freshwater. However, anthropic activities such as agriculture and livestock must be controlled, since animal waste and fertilizers may become sources of this nutrient (Cleemput and Boeckx, 2005). The nitrogen content varied from $1.44 \mathrm{mg} \mathrm{L}^{-1}$ in the Jotuba River (J2) in May (WB), to the DL $\left(<0.01 \mathrm{mg} \mathrm{L}^{-1}\right)$. In the same month, significant values were also observed at the remaining collection points. Nitrite oscillated between $<0.001$ (DL) and $0.031 \mathrm{mg} \mathrm{L}^{-1}$ in the reservoir (R4) in March (WB). Nitrate varied between $<0.01$ (DL) and $4.50 \mathrm{mg} \mathrm{L}^{-1}$ in the Jotuba River (J2), also in March. These parameters are in line with the limits stipulated by Conama 357/05 for Class II.

The sampling for the cyanobacteria count with reference to the water treatment process for human consumption was conducted near the Alagados water collection (R4). In accordance with Directive 2,914/11, the sampling for evaluating the cyanobacteria has been conducted monthly, but whenever the observed value surpasses 20,000 cell $\mathrm{mL}^{-1}$, it is conducted weekly. The blooming began at the end of January, with a predominance of the genus Dolichospermum sp (Anabaena sp), but in February the dominance shifted to Cylindrospermospis sp and remained so until the end of the blooming period in June (Figure 4A). This predominance may be related to adaptive characteristics such as floatability, tolerance to variations in temperature, and capacity for absorbing and storing phosphorus (Andreoli and Carneiro, 2005; Wu et al., 2012).

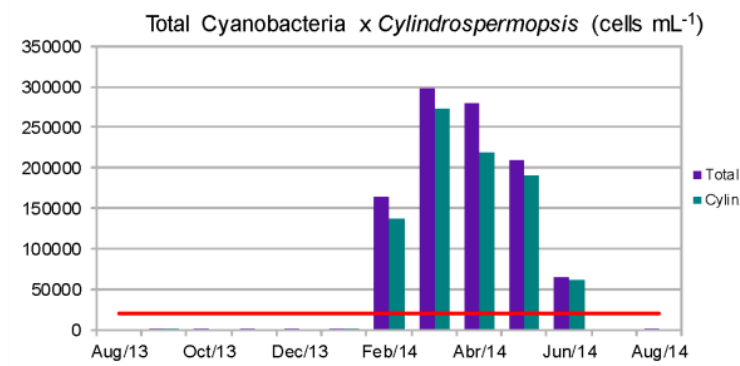

A

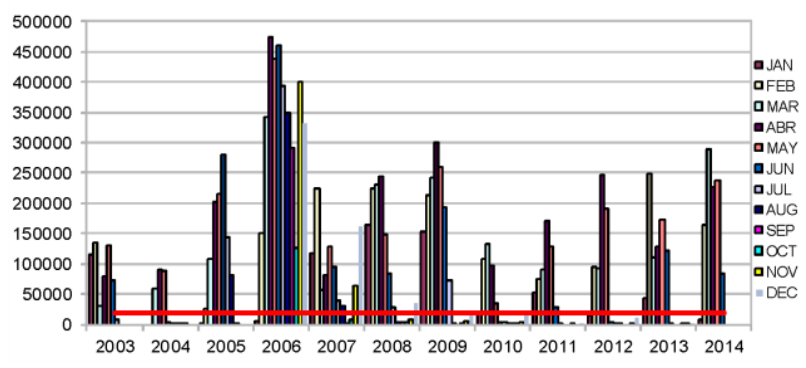

B

Figure 4. (A) Total cyanobacteria in relation to Cylindrospermopsis sp in the Alagados Reservoir from August 2013 to August 2014. (B) Record of the monthly averages for total cyanobacteria count in the Alagados Reservoir (January 2003 to August 2014).

*The highlighted value is the maximum permissible value (MPV) according to Directive 2,914/11 of the Ministry of Health.

Occasional bloomings in the Alagados Reservoir have occurred since 1980, but they have become more intense and more frequent since 2002, and have included the presence of cyanotoxins. Thus, the monitoring has been systematized since 2003, the same year in which changes in water quality and difficulties in its treatment were also observed by SANEPAR. The historical data for the blooming of algae (Figure 4B) reveal the seasonal nature of the phenomenon, which begins in the summer (Dec/Jan), peaks at the end of the summer (Mar/Apr) and concludes at the beginning of winter (Jun). The peak in cyanobacteria observed during the year of the study was higher than that of the historical data for the previous five years (Figure 4B).

Saxitoxins and microcystins were within the legal limits, the largest saxitoxin values being observed in the months of February, March, and April, in agreement with the peaks in cyanobacteria density. On $05 / 12 / 14$, the observed content $\left(2.8 \mu \mathrm{g} \mathrm{L}^{-1}\right)$ was slightly less than the MPV defined by Directive 2,914/11 $\left(3.0 \mu \mathrm{g} \mathrm{L}^{-1}\right)$, and may possibly be related to the reduction in cyanobacteria, from 357,627 cells $\mathrm{mL}^{-1}$ to 176,615 cells $\mathrm{mL}^{-1}$, between $05 / 06 / 14$ and

\section{IPABH}

Rev. Ambient. Água vol. 13 n. 3, e2016 - Taubaté 2018 
05/12/14, resulting from its release into the water during its old age, death, or cell lysis (Hitzfeld et al., 2000).

\subsection{Influence of cyanobacteria blooming on the Water Treatment Stations (WTSs) of Ponta Grossa}

The presence of cyanobacteria in raw water required larger doses of chemical products such as coagulants and polymers (Table 1) in order to avoid their flotation; these larger doses consequently elevated the cost of production and monitoring of water quality in the system (Di Bernardo and Dantas, 2005; De Julio, et al., 2010).

Table 1. Monthly averages of the costs of several chemical products used in the WTSs of Ponta Grossa during periods of no blooming (NB) and with blooming (WB) from August 2013 to August 2014.

\begin{tabular}{lccc}
\hline & Price $(\mathbf{R} \$)$ & No blooming - NB (R\$) & With blooming - WB (R\$) \\
\hline Powdered activated carbon (kg) & 5.50 & $2,546.50$ & $50,655.00$ \\
Aluminum Polychlorite (kg) & 1.05 & $120,148.35$ & $143,650.50$ \\
Cationic polymer (kg) & 8.92 & $2,595.72$ & $3,139.84$ \\
\hline Total & & $\mathbf{1 2 5 , 2 9 0 . 5 7}$ & $\mathbf{1 9 7 , 4 4 5 . 3 4}$ \\
\hline
\end{tabular}

During the study period, the two WTSs treated $950 \mathrm{~L} \mathrm{~s}^{-1}$, and the average run time for the filters varied from 25.00 hours (NB) to 9.00 hours at the peak of blooming, thus raising rinsing water consumption by $278 \%$ (SANEPAR, 2014). Some sub products of algae, such as geosmin and 2-methylisoborneol (2-MIB), may produce undesirable tastes and odors (Di Bernardo and Dantas, 2005), which may be minimized by the use of activated carbon, which also reduces cyanotoxins. As a result, there was a $58 \%$ increase in spending for material due to the additional consumption of activated carbon $(1,889.2 \%)$, coagulant $(19.6 \%)$, and polymer $(21.0 \%)$, in addition to increases in other costs such as the intensification of the water quality monitoring process, especially in the counting of cyanobacteria and evaluation of cyanotoxins (saxitoxins and microcystines). Finally, the blooming also affected other aspects, such as the rational reuse water system of the WTSs. The water used to wash the filters is stored in a tank for its later reintroduction into the treatment process; however, this activity may disseminate algae because some species of cyanobacteria are capable of reproduction in closed environments and may liberate cyanotoxins (Hrudey et al., 1999). In the case of the WTSs in Ponta Grossa, the interruption of the water reintroduction results in an average loss of $50 \mathrm{~L} \mathrm{~s}^{-1}$, thus limiting its availability during periods of high demand, such as in hot periods.

Other precautions may also be necessary in addition to the extra attention given to the supply system. SANEPAR provides the hemodialysis unit of the Santa Casa de Misericórdia Hospital in Ponta Grossa using subterranean water originating in a well. This avoids the problem of blooming and prevents serious accidents resulting from the presence of cyanotoxins in the water used for hemodialysis, such as what occurred in Caruaru-PE in 1996 (Hitzfeld et al., 2000). Together, these aspects lead one to believe that an understanding of the phenomenon of blooming is an essential part of environmental and economic sustainability in the water treatment station.

\subsection{Analysis of Water Quality by WQI}

The blooming altered the quality of the water being treated (Table 1) during the months of February through June. The WQI of the reservoir at R1, the junction of the Jotuba and Pitangui Rivers, exhibited the best WQI (Water Quality Index) levels (Table 2), followed by R4, the point near the water collection. The WQI of surface water was on average similar, considering 
the months in which samples were collected from all points, or slightly better than at a depth of $3 \mathrm{~m}$ and better than the reservoir bed, results that are compatible with the residues that are also sampled. The WQI varied between 42, at the bottom of the reservoir (March of 2013) and 92 at the juncture of the rivers (June of 2014). The worst case corresponds to the greatest number of cyanobacteria observed $\left(372,536\right.$ cells $\left.\mathrm{mL}^{-1}\right)$, as well as the transparency of $0.2 \mathrm{~m}$, this property being affected basically by two factors: algae and material in suspension. Other parameters that caused the low WQI in the reservoir were COD, TP, and TN. The E. coli, considered in the river WQI, remained below 1,000 NMP $\mathrm{mL}^{-1}$ for most of the study period, exhibiting better WQIs at the point of junction between the Rivers Jotuba and Pitangui.

Table 2. Water quality index at the points R1 (junction of the Jotuba and Pitangui Rivers) and R4 (point near the water intake for public supply) of the Alagados Reservoir from August 2013 to August 2014.

\begin{tabular}{lcccc}
\hline & Tributaries - R1 & \multicolumn{3}{c}{ Alagados Reservoir $-\mathbf{R 4}$} \\
\hline Date & Junction of Jotuba and Pitangui rivers & Surface & 3 meters & Floor \\
\hline $\mathbf{0 8 / 2 6 / 1 3}$ & 83 & 85 & 80 & 81 \\
$\mathbf{0 9 / 3 0 / 1 3}$ & 91 & 85 & 86 & 61 \\
$\mathbf{1 0 / 2 8 / 1 3}$ & 87 & 83 & 82 & 70 \\
$\mathbf{1 2 / 0 2 / 1 3}$ & 87 & 88 & 87 & 86 \\
$\mathbf{0 1 / 2 7 / 1 4}$ & 76 & 75 & 73 & 67 \\
$\mathbf{0 2 / 2 4 / 1 4}$ & $\mathrm{NC}$ & 46 & $\mathrm{NC}$ & $\mathrm{NC}$ \\
$\mathbf{0 3 / 3 1 / 1 4}$ & 83 & 44 & 43 & 42 \\
$\mathbf{0 4 / 2 2 / 1 4}$ & $\mathrm{NC}$ & 56 & $\mathrm{NC}$ & $\mathrm{NC}$ \\
$\mathbf{0 5 / 2 6 / 1 4}$ & $\mathrm{NC}$ & 55 & $\mathrm{NC}$ & $\mathrm{NC}$ \\
$\mathbf{0 6 / 3 0 / 1 4}$ & 92 & 80 & 80 & 63 \\
$\mathbf{0 7 / 2 8 / 1 4}$ & 90 & 80 & 82 & 76 \\
$\mathbf{0 8 / 2 5 / 1 4}$ & 87 & 83 & 84 & 76 \\
\hline General Average & $\mathbf{9 0}$ & $\mathbf{7 2}$ & $\mathbf{8 2}$ & $\mathbf{7 2}$ \\
\hline NB Average & $\mathbf{8 6}$ & $\mathbf{8 3}$ & $\mathbf{8 2}$ & $\mathbf{7 4}$ \\
\hline WB Average & $\mathbf{8 8}$ & $\mathbf{5 6}$ & $\mathbf{6 2}$ & $\mathbf{5 3}$ \\
\hline
\end{tabular}

$\mathrm{NC}$ - Not conducted due to the low water levels of the reservoir (access by boat was impeded by the presence of tree trunks and sandbars).

Scale: 100 to 90 (excellent), 89 to 70 (good), 69 to 50 (normal) and 49 to 0 (poor) (SANEPAR, 2014).

\subsection{Evaluation of cyanobacteria blooming by PCA and HCA in relation to the geographical, physical, chemical, and biological parameters of the reservoir}

The number of cyanobacteria cells per $\mathrm{mL}$ of water of the reservoir was scaled according to four classes, following Brazilian legislation (Table 3) in order to conduct a qualitative exploration of the six geographical, nine chemical, four physical and three biological variables.

Table 3. Classes created in order to discriminate among cyanobacteria bloom intensities.

\begin{tabular}{lll}
\hline Class & Cianobacteria $\left(\right.$ cells $\left.\mathbf{~ m L}^{-1}\right)$ & Reference for decision \\
\hline $1\left(\right.$ gray $\left.^{*}\right)$ & Up to 2.000 & WHO recommendation. \\
$2\left(\right.$ red $\left.^{*}\right)$ & More than 2,000 to 20,000 & MPV by directive 2,914/2011 of the Ministry of Health. \\
$3\left(\right.$ green $\left.^{*}\right)$ & More than 20,000 to 50,000 & $\begin{array}{l}\text { MPV with reference to Class 2 Fresh Water, framework of } \\
\text { Resolution 357/2005 of CONAMA. }\end{array}$ \\
$4\left(\right.$ pink $\left.^{*}\right)$ & More than 50,000 & $\begin{array}{l}\text { Value above the framework for Class 2 Fresh Water, Up to } \\
100,000, \text { framework for Class 3 Fresh Water according to } \\
\end{array}$ \\
& Resolution 357/2005 of CONAMA. \\
\hline
\end{tabular}

*Color of class illustrations in the corresponding figures.

\section{IPABH}

Rev. Ambient. Água vol. 13 n. 3, e2016 - Taubaté 2018 
The qualitative exploratory evaluation by multivariate calibration (PCA) of cyanobacteria required scaling. The variance, in order to be high, would require more than 10 components of a total of 21. The s0804 database (Apr/08) exhibited atypical behavior, with $\mathrm{NH}_{3}$ (5.69 $\left.\mathrm{mg} \mathrm{L}^{-1}\right)$, TP (1.66 mg L $\left.\mathrm{m}^{-1}\right), \mathrm{RP}\left(1.39 \mathrm{mg} \mathrm{L}^{-1}\right)$ and turbidity (46.8 NTU) being much higher than their respective averages, which were $0.31,0.08,0.04$, and 11.96. This fact may be attributed to the rain during the 24 hours that preceded collection, or else to some sampling error. The PCA did not exhibit any discrepancy among the samples (Figure 5) without this body of data, but it also did not reveal any subgroups with class grouping, which was confirmed by the Hierarchical Clustering Analysis (HCA) dendrogram (figure not shown). This confirms the complexity of the system in view of the present information and the necessity of further studies in which the sampling frequency and analysis methodology must also be re-evaluated.

Some variables, such as climate conditions, rainfall index of the reservoir, and reservoir water level, exhibit a compatible correlation. For example, more rainfall results in more precipitation and consequently a raise in reservoir levels. Another example is the intimate relationship between BOD and COD, since there is no affluent industry with inorganic technology that justifies a different phenomenon. On the other hand, there were some correlations that were not possible to justify based on current understanding, such as the correlation between nitrite and E. coli, and both of these parameters with insolation; another example is turbidity with ammonia, and both of these with DO.

The difficulties found in PCA and HCA statistical analysis may be due to the complexity of the environmental process or changes in analysis methodology during the historical period studied (2008 to 2014), which attempted to obtain lower detection limits, in addition to the technical impossibility of sampling during each of the periods, such as during the dry season. Thus, the physical-chemical and biological databases must be extended, and socioeconomic factors involving soil usage and occupation, and technology employed in the area must be taken into account. These data would aid in the construction of an overall picture and could be used to predict the quantity and quality of the water in the Alagados reservoir, thus allowing the establishment of guidelines for planning, environmental monitoring, nutrient input, and sustainable usage.

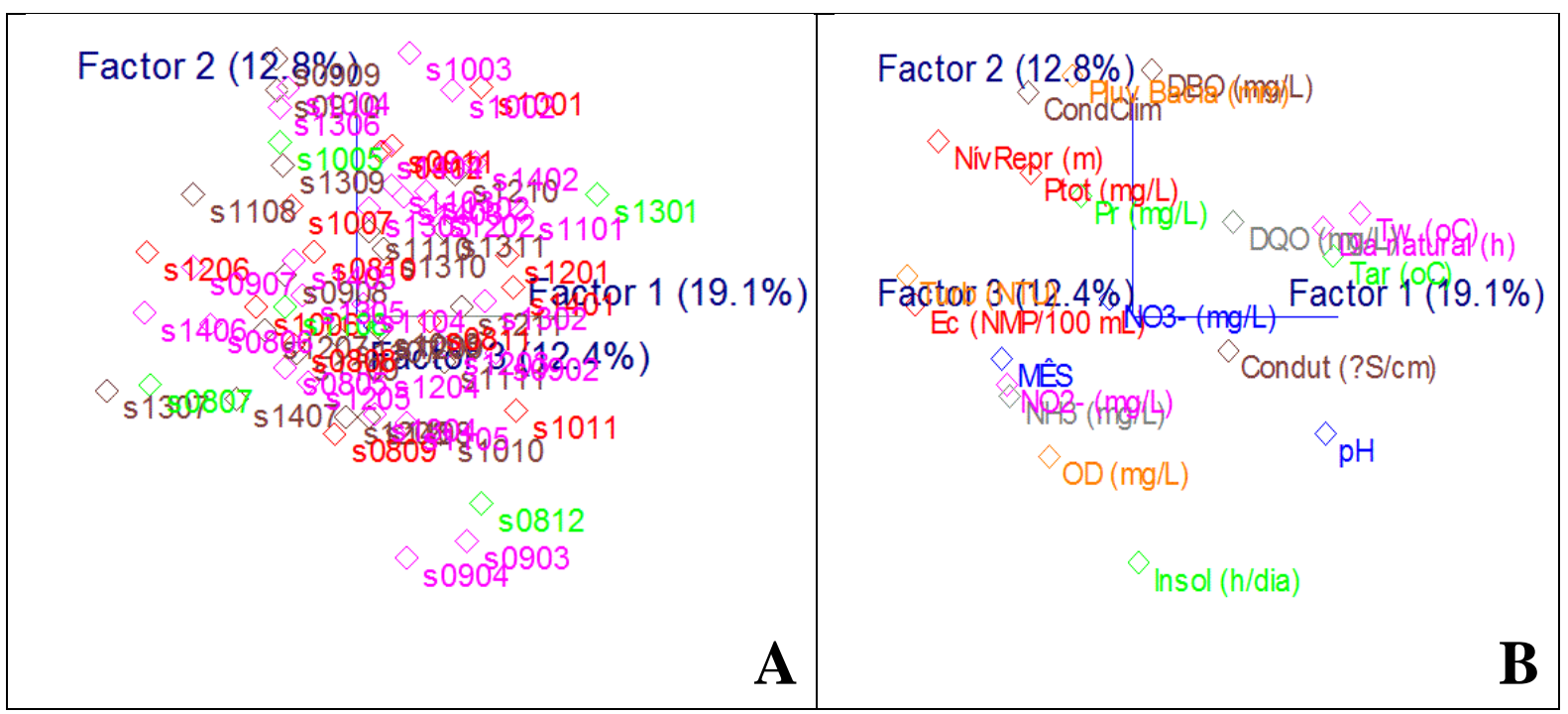

Figure 5. (A) Scores and (B) loadings without the s0804 grouping, for the first three PCs. Color key: Class I (gray), Class II (red), Class III (green) and Class IV (pink). 


\section{CONCLUSION}

The blooming of cyanobacteria in the Alagados Reservoir in Paraná, Brazil, has been occurring yearly during the summer and autumn months. The potentially toxic Cylindrospermopsis sp has been predominant. The quality of the water in the reservoir was significantly worse between February and May of 2014, attributable to the decrease in transparency (due to the presence of cyanobacteria and material in suspension), as well as to the levels of chemical oxygen demand, total phosphorus, and total nitrogen. The low water level in the reservoir and greater insolation temperatures (as a result of the low levels of rainfall in the summer of 2014) were probably important factors involved in blooming. It was not possible to correlate statistically the physical, chemical, and biological parameters with blooming due to the ecological complexity of the process. Therefore, it is recommended that the study be extended and exact and precise methodologies be used. In addition, it is recommended that socioeconomic factors involving soil usage and the technology employed in the region be taken into consideration.

The blooming negatively affected the water treatment process conducted by two SANEPAR stations. Greater quantities of chemical products such as activated carbon $(1,889 \%)$, coagulant $(19.6 \%)$, and polymer $(21.0 \%)$ were needed to treat the water during the blooming period, resulting in that these aspects alone caused a 58\% increase in cost, as well as rendering impossible the reuse of water during the process.

\section{REFERENCES}

ANDREOLI, C. V.; CARNEIRO, C. Gestão integrada de mananciais de abastecimentos eutrofizados. Curitiba: Editora Gráfica Capital, 2005, 500 p.

CASTRO, L. M. A. de; BAPTISTA, M. B.; BARRAUD, S. Proposição de Metodologia para Avaliação dos Efeitos da Urbanização nos Corpos de Água, Revista Brasileira de Recursos Hídricos, v. 14, n. 4, p. 113-123, 2009.

CLEEMPUT, O. V.; BOECKX, P. Alteración del ciclo del nitrógeno por las actividades agricolas, sus consecuencias ambientales y sobre la salud humana. Gayana Botánica, v. 62, n. 2, p. 98-109, 2005. http://dx.doi.org/10.4067/S0717-66432005000200005

COMPANHIA DE SANEAMENTO DO PARANÁ - SANEPAR. Avaliação ambiental da represa do Alagados, manancial de Ponta Grossa-PR. Parecer Técnico 034/2010USHI. Curitiba, 2010.

COMPANHIA DE SANEAMENTO DO PARANÁ - SANEPAR. Relatórios Internos. Ponta Grossa, 2014.

CONLEY D. J.; PAERL, H. W.; HOWARTH, R. W.; BOESCH, D. F.; SEITZINGER, S. P.; HAVENS, K. E. et al. Controlling Eutrophication: Nitrogen and Phosphorus. Science Policy Forum, v. 323, p. 1014-1015, 2009. http://dx.doi.org/10.1126/science.1167755

DE JULIO, M.; FIORAVANTE, D. A.; SELHORST FILHO, O.; GRAHAM, N. J. D. Remoção de cianobactérias de água proveniente de manancial Brasileiro eutrofizado, utilizando os diagramas de coagulação para o sulfato de alumínio e PAC. Engenharia Civil - UM, n. 37, p. 47-61, 2010. https://doi.org/10.4995/ia.2010.2972

DI BERNARDO, L.; DANTAS, A. D. B. Métodos e técnicas de tratamento de água. São Carlos: RIMA, 2005. 1565 p. 
HITZFELD, B. C.; HÖGER, S. J.; DIETRICH, D. R. Cyanobacterial Toxins: Removal during drinking water treatment, and human risk assessment. Environmental Health Perspectives, v. 108, p. 113-122, 2000.

HRUDEY, S. E.; BURCH, M.; DRIKAS, M.; GREGORY, R. Toxic Cyanobacteria in Water: A guide to their public health consequences, monitoring and management. London; New York: E \& FN SPON, 1999. 400 p.

JACOBY, C. A.; FRAZER, T. K. Eutrophication: Time to adjust expectations. Science, v. 324, p. 723-724, 2009. http://dx.doi.org/10.1126/science.324_723b

NAKAMURA M.; RAST, W. Development of ILBM Platform Process: Evolving Guidelines through Participatory Improvement. Japan: RCSE; Shiga University; ILEC, 2011. 82 p.

SOSNOVSKY, A.; QUIRÓS, R. El estado trófico de pequeñas lagunas pampeanas, su relación con la hidrologia y el uso de la tierra. Ecología Austral, v. 16, n. 2, 2006.

TUCCI, C. E. M.; MENDES, C. A. Avaliação Ambiental Integrada da Bacia Hidrográfica. Brasília: Ministério do Meio Ambiente, 2006. 302 p.

WETZEL, R. G. Limnology. San Diego: Academic Press, 2001. 1006 p.

WU, Z.; ZENG, B.; LI, B.; SONG, L. Physiological regulation of Cylindrospermopsis raciborskii (Nostocales, Cyanobacteria) in response to inorganic phosphorus limitation. Harmful Algae, v. 15, p. 53-58, 2012. http://dx.doi.org/10.1016/j.hal.2011.11.005

YUNES, J. S.; CUNHA, N. T.; BARROS, L. P.; PROENÇA, L. A. O.; MONSERRAT, J. M. Cyanobacterial neurotoxins from southern Brazilian freshwaters. Comments on Toxicology, v. 9, n. 2, p. 103-115, 2003. http://dx.doi.org/10.1080/08865140302426 